International Journal of Linguistics, Literature and Translation

ISSN: 2617-0299 (Online); ISSN: 2708-0099 (Print)

DOI: 10.32996/ijltt

Journal Homepage: www.al-kindipublisher.com/index.php/ijltt

\title{
The Impact of Storytelling and Cooperative Learning on Iranian EFL Learners Vocabulary Achievement
}

\author{
Zeynab Rezaei Gashti 8 (D) \\ Department of Literature and Foreign Languages, Islamic Azad University of Karaj, Karaj, Iran \\ $\square$ Corresponding Author: Zeynab Rezaei Gashti, E-mail: elhamrez648@yahoo.com
}

\section{ARTICLE INFORMATION}

Received: April 11, 2021

Accepted: May 05, 2021

Volume: 4

Issue: 5

DOI: $10.32996 /$ ijllt.2021.4.5.5

\section{KEYWORDS}

Achievement, Cooperative

Leaming. Storytelling, Vocabulary

\section{ABSTRACT}

The researcher investigated the effect of using short stories and cooperative learning together in one class and compared its effect with the existing traditional methods and cooperative program as well as contextualized short-story-based program. To do so, 75 Iranian female EFL learners participated in the study after a homogeneity test. They were divided into three groups i.e., storytelling, cooperative, and mixed. The learners in the cooperative group followed the above procedures of cooperative learning for reading short stories and the short story group was engaged in a question and answering activity was guided by the teacher, as mentioned earlier. Moreover, the mixed group covered the short stories extensively out of the class as described for the short story group and did the cooperative group work activity in class. After the treatment lasted 12 sessions, the learners took the test again. The study's findings reveal that using story-telling can be a good strategy to bypass the difficulty of vocabulary instruction insomuch it gives leaners chances of using new words communicatively to produce target forms in meaningful real-world contexts.

\section{Introduction}

English is one of the essential foreign languages taught in many countries. The first and foremost crucial element in all languages is a word. In the way we can learn first or any other languages like English, everyday words are made and acquired, even in our first language (Namaziandost, Homayouni, \& Rahmani, 2020). Shakibaei, Shahamat, and Namaziandost (2019) argue that people leam vocabulary before they start communication. In the natural cycle of listening., speaking, reading, and writing in a first or a second language, they must have the vocabulary to convey or understand the meaning of the ideas. Even in the process of EFL leaming. Learners have more vocabularies to learn. The importance of vocabulary learning is emphasized by a French proverb that says, "Word by word the book is made". Craig (1996), in his Storytelling in the Classroom: Some Theoretical Thoughts, argues that storytelling in first language acquisition is compelling for children's social skills, mental and literacy development. And the story is, by its nature, fundamentally a listening activity that fits in with the silent period theory recommended in the early stages of language learning by several experts such as Krashen and Terrell in The Natural Approach.

Group activities have to be one of the basic tools in the communicative language teachers' box because groups provide so many chances for learners to communicate and means of integrating, listening, speaking, reading, writing. Though, despite the many benefits of group activities, difficulties also arise- difficulties have led some educators to give up or apply group work (Dabaghmanesh, Zamenian \& Bagheri, 2013). These difficulties include "members not participating, groups not getting along, or learners unable to do the task. Cooperative learning arose in mainstream education as an effort ta address such difficulties and to generally expedite student-student interaction" (Harmer, 2005, p. 126).

The stories are usually used in the first language and mainly for child literacy, but in foreign language teaching, the stories can be used for different ages and levels though they work better with intermediate level students and above. For choosing the

\begin{tabular}{lll|l} 
K & C & AL-KINDI CENTER \\
$\mathbf{R}$ & D & FOR RESEARCH AN
\end{tabular}

$\mathbf{R}$ D FEVELOPMENT

Your gateway to world-class research

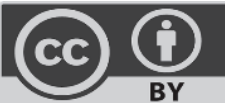

Published by Al-Kindi Center for Research and Development, London, United Kingdom. Copyright (c) the author(s). This open access article is distributed under a Creative Commons Attribution (CC-BY) 4.0 license 
stories the language and the content are of paramount importance. They need to be tailored to the moods of the students. While adopting this approach in teaching vocabulary through meaningful communicative context, this research attempts to compare applying such an approach to presenting grammar issues to EFL learners with the traditional deductive decontextualized approach common in school settings in Iran. To this date, numerous research studies have been conducted to convey the effect of storytelling on language learning (Gorjia, Moosavinia \& Shahramiri, 2011, Nasri, \& Namaziandost, 2019; Pishghadam \& Motakef, 2012). Most foreign language learners hurt by a lack of vocabulary knowledge, even at an upper intermediate level of language proficiency. Undeveloped ways of improving vocabulary knowledge are the main reason for so many attempts to establish different kinds of activities to foster it. Among these activities, innovative teaching techniques such as storytelling and cooperative learning can be examined. Moreover, the researcher is willing to consider the collaborative aspect of these orientations to teaching vocabulary. To this end, the researcher is interested in probing the effect of adopting group work and cooperative tasks on vocabulary learning and compares the effect with the contextualized program using short stories. Finally, the researcher investigates the effect of using short stories and cooperative learning together in one class and compares its effect with the existing traditional methods and cooperative program as well as contextualized short-story-based program.

Most of the articles discussed above support the use of stories for learning and teaching of speaking, listening, writing and, a few of them, grammar. Considering the literature, only Zawada (2012) and Soleimani and Khandan (2013) have specifically investigated the effect of storytelling as a tool for teaching simple past tense to learners aged 11-13 and the effect of teacher's telling short stories on the acquisition of grammatical rules and structures (conditional sentences type I, II and III) of the Iranian English as a foreign language (EFL) learners, respectively. Although they have worked on this issue, none of the studies have done a comparative study to evaluate the effect of storytelling mixed with other teaching methods. The present study will attempt to investigate the effect of telling stories and cooperative learning on vocabulary learning of Iranian EFL learners. It is hoped that the results of the present study could contribute to the improvements in teaching grammar in different EFL settings. It is expected that teachers, syllabus designers, material developers and teacher trainers enjoy the results of this study.

\section{Research Questions and Null Hypotheses}

In order to serve the purpose of the research, several questions and hypothesis are raised: 1. Does vocabulary instruction through story-telling exert any significant impact on EFL learners' vocabulary achievement?

2. Does vocabulary instruction through cooperative learning exert any significant impact on EFL. learners' vocabulary achievement?

3. Does vocabulary instruction through storytelling and cooperative learning affect EFL learners' vocabulary achievement?

\section{Hypotheses}

H0 1. Vocabulary instruction through storytelling does not significantly impact EFL learners" vocabulary achievement. HO 2. Vocabulary instruction through cooperative lear $n$ ing does notsignificantly impact EFL learners' vocabulary achievement. HO 3. Vocabulary instruction through storytelling and cooperative lear $n$ ing does notsignificantly impact EFL learners' vocabulary achievement.

\section{Review of the Related Literature}

\subsection{The Nature of Vocabulary Learning}

As students experience difficulty when trying to comprehend some texts, they need instruction to help them know the unknown or unfamiliar words they encounter. Educators are responsible for providing the maximum opportunity for all students to gain access to knowledge about the academic discourse needed to succeed in schools (Soatt, 2005). One possible step for improving a student's vocabulary knowledge is to teach effective word learning strategies that help students understand and learn specialized vocabulary (Allen, 1999). However, to know if this is a good solution, it is essential to look at the vocabulary strategies being taught and determine if the strategies being used are effective or if new strategies need to be taught. There are two basic types of vocabulary instruction (a) intentional and (b) incidental. Beck and McKeown (1991) define intentional vocabulary instruction as instruction with the explicit purpose to teach the meaning of a word. An example of intentional instruction is when a teacher directly provides one or more resources, such as a dictionary or a more knowledgeable person, with the strict intention of having the student learn the meaning of a word. Beck and McKeown (1991) continue by describing incidental vocabulary instruction as to when the explicit purpose of the interaction with the word is not to learn the word's meaning. Rather, the purpose of instruction may focus on something other than learning a word's meaning, but the student learns the word's meaning throughout the interaction. Beck and McKeown(1991) claim that students learn words incidentally through oral conversations and media or written documents such as letters, magazines or books. According to him, the two most repeated methods used to learn word definitions in classrooms are the dictionary or definition method ,(intentional) and the context method (incidental) . 
Hornby (1995) defines vocabulary as the total number of words in a language; vocabulary is a list of words with their meanings. While Ur (1998) states vocabulary can be defined, roughly, as the words, we teach in the foreign language. However, a new vocabulary item may be more than just a single word: the post office and mother-in- law, which are made up of two or three words but express a single idea. A useful convention is to cover all such cases by talking about vocabulary "items" rather than "words". In addition, burns (1972) defines vocabulary as" the stock of words which the person, class or profession use. According to Zimmerman cited in Coady and Huckin (2005) vocabulary is central to language and of critical importance to the typical language learning Furthermore, Zawada (2012) in www.readingrockets.org/articele state that vocabulary is the knowledge of words and words meanings ". Techniques of vocabulary learning are a useful instrument for independent vocabulary learning that is helpful in class practising.

One of the components of direct, explicit instruction is to explain how to use context clues to determine the meanings of unknown words. Francis, Simpson, and Stahl (2004) refer to this as a generative approach that emphasizes the importance of creating lifelong learners of words by teaching such techniques as context clues to unlock the meaning of words on an independent basis. Context clues can be provided in a variety of ways through synonyms, antonyms, general contexts, or examples. "Teaching students how to use context to determine a word's meaning should be an important component of a comprehensive vocabulary program" (Ellis, 1999, pp. 143-144 ). With the exception of general context clues that use common sense, the other clues may provide readers with punctuation marks or keywords that indicate they will get a synonym, antonym, or example of the unknown term to help them unlock the meaning. One example is, "Please pick up the "refuse" or "garbage" in front of the house" or "She offered the man a modicum of gratitude for his hard work instead of the significant amount of gratitude he deserved ". While teaching context clues is beneficial, in some cases, there are not enough clues provided to aid the reader in identifying the unknown word or the use of context clues may be helpful only across multiple encounters with words. In a study by Wang (2006), students demonstrated a general weakness in word knowledge and an inability to make sense of the target words by means of contextual clues. This could indicate that the text being read has too many challenging or unknown words or that an understanding of how to use context clues is unknown. If students are provided with "refuse" as a synonym for debris," neither word may be in their existing schemats, making it difficult if not impossible to unlock the meaning. The term "refuse" is also a homograph, which further confuses the meaning of the text. Context clues are not always sufficient and may require a fair degree of background knowledge before they can be effective learning tools. (Sinatra \& Dowd, 1991) Relying strictly on context clues to determine the meaning of unknown words can present major obstacles for second language learners who may not be able to connect with the text. Another study that challenges the effectiveness of using context clues is the work of Francis and Simpson (2004) Their research found that many students struggle to determine the meaning of unknown vocabulary because of the amount of information in the text. Additionally, these students will skip critical words they think they know, but their word knowledge is superficial or at a rote level wherecontext clues are less effectiv e.

A powerful approach to direct, explicit instruction is to teach students the strategy of using roots and affixes to determine the meaning of morphologically complex words. Teaching words parts is an extension of using context clues to unlock the meaning of unknown words. Beginning in the early elementary grades and continuing into the college years, teaching root words and affixes is a primary strategy that is used to increase one's knowledge of difficult vocabulary (Larse \&Nippold, 2007).

A study by Anglin (1993) on vocabulary growth between first and fifth grade showed an increase of approximately 4,000 root words by students. At the same time, the number of derived (prefixed or suffixed) words grew by about 14,000 words. An excellent example of how easy it is to get to the meaning of new or unknown words can be seen in the basic instruction of the prefix "a," meaning "not" in the word atypical. Experience demonstrates that virtually every student knows the meaning of typical, but not atypical. The focus on root words and affixes helps them to see how to unlock the meaning of new and unknown words in the future. According to Aghlara and Hadidi Tamjid (2011), 20 prefixes account for 97\% of prefixed words that appear in printed school English (p. 42). In Spanish, French, and English, the root ". dur. " means "hard" or "lasting. Including root word and strategy, instruction can be extremely valuable to native speaking English students and students who have a first language that is not English, but this methodology is built on Greek or Latin cognates. Many of the romance languages have the infrastructure of their language developed around Greek and Latin.

Additionally, the English language shares many cognates with other languages where words have similar meanings, pronunciations, and spellings which can aid in determining the meaning of unknown words. Unfortunately, those second language students who do not have a first language based on Grock or Latin may not succeed with this vocabulary instruction. The use of cognates to develop literacy and specific vocabulary is rooted in education strategies that reach back to the middle ages. The implication is that teaching reading and teaching vocabulary must expand beyond the pawer to read and understand the English language. 


\subsection{Storytelling and TEFL}

For example, one of the effective ways for teaching a language to EFL learners is using childish tale and academic stories because teachers can focus on more pleasant, practical, and useful methods in teaching vocabularies, grammars. Also, learners can learn a language because of time, good memory and so on (Urbancova, 2006). Therefore, teachers must connect language teaching very closely to the students' everyday interests; they must be encouraged to respond to texts and situations with their own thoughts and experience instead of answering questions and doing abstract learning activities. Teenagers face learning issues directly in a way. They need helpful feedback on whatever they do Harmer (2005). Urbancova (2006) believe that stories play an important role in learning and increasing the first language of humans and vice versa. Stories are important parts of teaching the languages in foreign languages. The teachers should start teaching a language with stories. "Many stories contain natural repetitions of key vocabularies and structures" (Ellis \& Brewster, 2002, p. 2). These will influence learners to memorize every part to predict what will happen next in the real future context. Stories work as a stimulator for learners. They "can help develop positive attitudes towards the foreign language, culture and language learning" (Ellis \& Brewster, 2002; p.1). Utilizing "stones allows the teacher to introduce or revise new vocabulary and sentence structures by exposing the children to language in varied, memorable and familiar contexts, which will enrich their thinking and gradually enter their own speech" (Ellis \& Brewster, 2002, p.2).

According to Hill (2001, p. 29) "There are many advantages of using stories in the classroom through using contemporary popular stories, which are already familiar to teenagers, the teacher can meet the challenges of the teenage needs in the classroom. Since stories are motivating, they may constitute a powerful subculture with their Own rituals." Ellis (1999) believes that storytelling is the best example of whole language pedagogy and it teaches a higher level of thinking skills, analyzes the needs of students with different learning styles, provides an opportunity for cooperative learning and building social skills and most importantly, storytelling builds intrinsic motivation and self-confidence, even in the students who try hard to reach. Fitzgibbon and Wilhelm (1998) believe that a range of creative storytelling mater materials and ideas for second language learning is available for the teachers. They think their benefits are higher student enjoyment, lower affective filters, realistic and developed language input, and collaborative classrooms. Stories appear to enable students to use their own experiences and organize information in personalized ways, leading to better comprehension and retention of the information and concepts. Also, storytelling may work as a connection to grammar learning because it shows grammatical and syntactic features in a meaningful context. As Kowalski (2001) says, storytelling shows a different use of tense and linking devices in organizing ideas. By using a careful design of learning activities, the teacher can draw learners' attention to specific linguistic features in the story presentation.

\subsection{Cooperative Learning}

Learning is actually a learner-centred language teaching method. In this method, learners' study by helping each other in pairs or grows to reach a goal previously set in the program. Cooperative learning is an educational idea that has different instructional methods in which learners work in small groups of 2-6, and their performance is supported by positive reinforcement. Cooperative learning happens in a class and is a learner-centred approach that helps learners make a positive image of themselves and their peers. This method is best for teaching problem solving and critical thinking. Also, it helps learners to develop social skills (Namaziandost, Shatalebi, \& Nasri, 2019). In cooperative learning, learners help each other with their learning by making small groups to reach a pre-defined goal. The cooperative learning method has a number of features: 1 . Learners must communicate with one another. Without communication, there is no group work. 2. In cooperative learning, learners 'efforts are rewarded as a group. 3. There is a sense of responsibility among the learners. In simple words, group members should know that materials prepared by all group members are for the sake of the group's success (Namaziandost, Hafezian, \& Shafiee, 2018). Group work is considered a cooperative learning task if the following conditions are met: 4. Group reward: In order for members of a group to succeed, the group itself must become successful. 5. Positive interdependence: It creates a situation in which individuals make a common effort for the reward and their common goal which can in fact be possible via positive dependence, positive product dependence, and positive process dependence. 6 . Individual accountability: It means that group success depends on the learning of each and every individual. Every learner has the responsibility to learn the subject and do whatever must be done. 7. Face-to-face promoted interaction: It means that group members motivate one another. 8. Social skills: It is about teaching learners how to build relations among individuals and encouraging them to use this. 9. Group processing: It is about identifying which behavior of the members benefit the group's success and which behaviors should continue and which ones should be modified. 10.The opportunity for equal success: It is about to benefit the group's success by developing their own behaviours and this can be achieved through a specific grading method "(Bolukbas, Keskin, \& Polat, 2011, p. 19). In a cooperative learning method, the objectives are achieved when the group is successful. Therefore, if a member wants to be successful, he or she has to help other group members. Bolukbas et al. (2011) believe that cooperative learning makes the best learners help weak learners to make their skills better. In other words, every learner tries to develop him or her and other members because they know that the group's success is the same as their success. In cooperative learning, a group is a whole and everybody is responsible for the success or the failure of the group. According to cooperative learning principles, there are different techniques available. Examples of these techniques are provided below: 1. Learning Together 2 . 
Academic Conflicts 3. Learners teams 4. Leaners Teams- Achievement Divisions 5. Team-Game-Tournament 6. Team Pair Solo 7. Cooperative Reading and Writing 8. Group Research 9- co-op 10. Jigsaw I 11. Discovery 12. Jigsaw II 13. Ask Together - Learn Together The teacher's leaning techniques are chosen based on the lesson goals, subject, learners' achievement levels, their skills, and the existing services in the educational location. If teachers and learners do not have the experience of using cooperative learning in language classrooms, they should start with simpler techniques. In this study, "Ask Together - Lean Together" is used based on Bolukbas, Keskin, and Polat (2011) because this technique has some instructional tasks which help the development and evaluation of listening comprehension skills in the classroom and it was the most suitable technique for using the cooperation in the classroom in this study.

Learning Cooperative learning offers many advantages in language classroom settings, such as reducing anxiety, increasing motivation, and assisting in the development of the language skills of learners. Cooperative language learning helps teachers create a positive affective classroom atmosphere in which psychological barriers, such as student anxiety, are lowered and selfconfidence and self-esteem are increased (Crandall, 1999; Dörnyei, 1997; Oxford, 1997). As Crandall (1999) states, students' anxiety results from the fear of making mistakes, especially when they are asked a question to be answered individually. When students are allowed to study together, they have more time to think, share their opinion with other students, receive feedback from them, and correct any mistakes. As a result, their anxiety level is reduced, and they become willing to answer the teacher's questions. One of the other reasons for anxiety is interpersonal competition among students Interpersonal competition may take place in traditional classes and causes high anxiety-Peer communication among students, a sense of uselessness. However, in intergroup competition, which is provided by cooperative learning, anxiety is reduced, interaction among students' increase and student confidence is enhanced. In language classrooms, where student anxiety is lowered and self-confidence and self-esteem are enhanced, it is not surprising that motivation increases. More motivated students in the language classroom tend to use the target language more which helps them improve their language proficiency. In cooperative learning groups, students assist their classmates in learning. Because each member of the group is responsible for his own learning and other members' learning, students support each other. In addition, because the groups have specific goals to achieve and sometimes a reward to win, cooperative learning activities are enjoyable for students. Enjoyable activities encourage learners to participate in lessons; hence they contribute to motivation (Tahmasbi, Hashemifardnia, \& Namaziandost, 2019). Brown (2010) concluded that engaging students in cooperative learning activities, especially those which focus on problem-solving, promotes intrinsic motivation which is crucial in learning. Cooperative language learning also empowers learners to acquire increased language skills.

\section{Related Studies}

Chia-Wen Chuc (2008) investigated the effects of memory strategy instruction on elementary school students' vocabulary learning. The results of this study claimed that after memory strategy instruction, participants in the experimental group applied memory strategies more frequently and their productive vocabulary performance improved. The results supported the positive influence of strategy training. That is, memory strategy instruction facilitated elementary school students" word spelling ability. In addition, both the more and less proficient learners' productive vocabulary ability significantly improved.

Romero (2009) in his article described a comparison between the effect of cooperative learning and the traditional method in the secondary and early post-secondary classroom on the basis of a systematic review of 2506 published and unpublished citations. The overall effect size (308) showed that cooperative learning increases students' accomplishment in science.

Jalilifar's (2010) investigation in which two Cooperative Learning techniques, including Student Team Achievement Divisions and Group Investigation, were used examined students' reading comprehension achievement of English as a Foreign Language. The researcher found that Student Team Achievement Divisions technique is more effective in improving EFL reading comprehension achievement in spite of the fact that both techniques could not improve reading comprehension significantly.

Another similar study but qualitative conducted by Momtaz and Garner (2010) investigated the effect of cooperative learning on students" reading comprehension in a non-western country (Iran) under question. Collaborative reading has significantly shown higher grades than private reading for all texts.

Javadi Rahavard (2010) explored the relationship between cooperative learning strategies and reading comprehension. Cooperative learning methods have been a major part of learning methodologist debates. The current paper studied the cooperative learning effect in EFL classes of Iranian learners quantitatively in an English institute at Bandar- Abbas. The Correlation coefficient formula using SPSS software, graphs and diagrams showed that cooperative learning strategies groups achieved significantly better results compared to their counterparts in a reading comprehension test.

Zarei and Keshavarz (2011) studied the effects of two models of CL on reading comprehension and vocabulary learning, with 132 Iranian participants. They reported the CL models' success compared with the non-cooperative control groups. 
Aghlara and Nasrin Hadidi Tamjid (2011) examined the effects of digital computer games on Iranian children's vocabulary retention in foreign language acquisition. The participants were 6 to 7 -year-old female learners with no prior knowledge of English. The results showed that using such games in the classroom resulted in better motivation and facilitated children's learning process and their cognitive achievement. As the researchers argued the leaming process become much more enjoyable and engaging children in such games considerably reduced the stress involved in the learning process.

Moreover, Tok (2012) investigated the relationship between cooperative leaming and achievement in English language acquisition in a literature class in a secondary school. Four instruments, including pre-test and post-test examinations, questionnaire, classroom observation, and interviews, were administrated. The results revealed a significant effect in the posttest of the experimental group. The qualitative part of the research indicated that using cooperative leaming strategies could improve learner's social behaviour.

In another study, Zahedia and Addi (2012) investigated the impact of imagery strategy on EFL learners" vocabulary learning, the result indicated that the experimental group outperformed the control group in terms of English vocabulary mastering using this strategy.

\section{Methodology}

6.1 Participants

Seventy-five Iranian female EFL learners participated in this study. They were all teenage language learners at an institute in Karaj. Their age range was between 13 to 17. They were selected based onaconvenient sampling procedure in which participants were selected based on their ease of access or availability to the researcher. However, to have a more representative sample, the participants were homogenized in their general language proficiency using Oxford Placement Test originally developed collaboratively by Oxford University and Cambridge University. The placement test was administered at the outset of the study and the participants whose scores fell in elementary level (21-30) were considered as the participants of this study. The learners in each proficiency level were randomly assigned toacooperation group, short story group, and mixed cooperationshort story group.

\subsection{Instruments}

The following instruments were used to assess the result of the study.

\subsection{Oxford PlacementTest (OPT)}

A placement test consisting 60 items was used to classify the students participating in this study into two levels. This test, (Referred to 3.2 participants) Oxford Placement Test OPT), consisted of four sections of grammar, vocabulary, reading and cloze items. The test ) will be administered in 60 minutes and the results are used to homogenize the participant.

\subsection{Vocabulary test}

There were two parallel 30-item tests of vocabulary used as pre-test and post-test in (Referred to in the text and procedure part) this study. These items are adopted from several short stories that will be covered in the class and then adapted into a single test. In order to test the usefulness of the instruments, a pilot study was conducted. In the pilot study, the tests were administere $d$ to a numberofmale learners at the intermediate level in the same institute and the results were analyzed through correlation analysis to ensure the parallel form reliability of the tests.

Post- test consisted of the new vocabulary items, which the teacher taught during the study, The pre-test consisted of 30 vocabulary items, and it was pieced together from different kinds of vocabulary tests. It consisted of four main parts. Two of the parts with 15items were formed to test vocabulary recognition and the other two parts with 15 items were formed to test vocabulary production. The vocabulary itemsused in the pre-testwere selected from the reading and listening texts in the participants' course books. The same reading and listening texts used for the experimental group were also used for the control group. After the study was completed, the post-test was administered to both the experimental and control groups to compare the two groups in terms of how well they learned vocabulary. The post-test covered the same vocabulary items used in the pretest with different kinds of activities. The researcher did not use the samepre-test as the post-test in case the participants remembered the questions. The researcher administered a different test as the post-test to increase the reliability of the study.

\subsection{Data Collection Procedure}

The purpose of this study was to compare the effects of two types of instructional treatments on vocabulary learning of EFL learners attheintermediate level with the same amount of time allocated to all groups. The short story group received vocabulary instructionby reading the short stories extensively out of the class and doing the fill-in-the-blank and matching exercises presented after the text. The short stories were from the book ".Steps to Understanding" by L A. Hills (2001) . The 
learners were asked comprehension summary and retelling questions in the class after reading the short stories to help the learmers to comprehend and recall the vocabulary better and checkthe leamers' covering of the story .

Moreover, it is worth mentioning that the target lexical items were highlighted in the passage to help the learners in the experimental groupnotice .

The learners in the cooperative group followed a program based on "Technique of Ask Together - Leam Together", This technique was developed by Stevens (2003). It is based on the principle of cooperation and gives priority to positive interdependence, individual accountability, group processing, reward, and face-to-face interaction.

In Ask Together - Learn Together Technique, the following materials could be exploited:

1- Reading: Some excerpts or sections taken from the books.

2- Question-Response Cards: These are the cards on which the group's questions and responses might be written, and their size might vary depending on the activity.

3- Theme Sheets: This is a paper on which important points to be considered during reading are listed.

4- :Group Presentation Evaluation Forms The teacher develops itto evaluate group presentations in terms of content and organization.

5- Examination: I consist of multiple-choice or short-response questions which were about the subject. It must not exceed 10-15 minutes (Bolukbash et al., 2011).

The following were also incorporated in this study using the Technique of Ask Together - Leam Together. These were adopted from Bolukbash et al. (2011).

1- Organizing groups: Groups ideally should consist of 3-4 learners. It is important to organize groups heterogeneously based on their skills, level of achievement, gender, and socio-economic status. Finding a name for each grouppositively affectsmotivating learners and attracting their attention to the lesson .

2- Listening: Each learner listens to .the related text or section individually and silentlyTheteacher might inform the learners about the important points to be considered during reading or the themes.

3- Preparation of Learner Quertions: It is the step at which learners are expected to prepare questions about the reading or the themes. They write the questions on a card. The teacher grades each question based on their level and accuracy, which is necessary to monitoreach learner's performance.

4- Preparation of Group Questions: Having prepared individual questions, members come together to prepare the group question. Leamers are expected to explaineach question's positive and negative aspectsto one another rather than tagging them as bad or good. In order to make sure learners' participation, learners are given roles in turns such as recorder, postman, reporter, debate leader, and invigilators or monitors.

5- Sending Group Questions: The question prepared by the group is written on a card and sent to another group chosen randomly by a student with the role of a postman.

6- Responding to Group Questions: This is another step requiring the cooperation ofthe group members. the fact that each group has only one question card is necessary due to positive interdependence.

7- Presenting Responses to the Class: By means of spokespeople that they have chosen, the groups present their response to the question they have to the whole class. In order to guarantee the learning of everyone in the group, the spokespeople can also be chosen by the teacher rather than the group members.

8- Evaluating Group Presentations: The performance of the spokesperson is evaluated by the teacher or other students. The teacher might give a form for this, and after the evaluation process, a point is given to the spokesperson and the group.

9- Whole-class Discussion: After the groups have completed their presentation, the teacher can start a discussion by summarizing the subjectThis discussion aimsto clarify the points that could not be focused on and not understood completely.

10- Testing: After the session is completed, all students take an exam individually. The points gathered from the exam and their presentations are summed up and a group point is measured. By comparing group points to previously "defined criteria and a scale, groups are given rewards which are also decided in advance such as "very good"good" "not bad".

In this study, steps 8 and 10 were not performed in the class due to lack of time in the class. Doing these steps made the teacher ignore other aspects of the class. It should be noted that the learners in the cooperative group did not cover the study at home and received it in the class.

In this group, the researcher asked the students to take the vocabulary test before the treatment on the first session. Then they were grouped. The learners in the cooperative group followed the above procedures of cooperative learning for reading short stories and the short story group was engaged in question and answering activity guided by the teacher, as mentioned earlier.

Page | 69 
Moreover, the mixed group covered the short stories extensively out of the class as described fortheshort story group and did the cooperative group work activity in class. After the treatment lasted 12 sessions, the learners took the test again.

\subsection{Design}

This study was considered to be quantitative research since it mainly relied on the numerical data, the test scores obtained from the tests (pretest and posttest). Moreover, this research project was of quasi-experimental pretest-posttest design. Since the researcher did not have the opportunity to conduct a true stratified sampling proce dure, there was no chance of devisingatrue experimental study. Accordingly, the independent variables of this research were cooperative instruction and using short-story. The dependent variable was vocabulary learning, and the moderating variable was the learners' proficiency level.

\subsection{Data Analysis}

In order to analyzed the data obtained from the tests descriptive statistical analysis was conducted to calculate mean score as well as standard deviations of the data sets. Then the normality of the distribution of the obtained data was tested. Moreover, ANOVA as well as paired sample T-test were used to compare pretest scores and post test according to the research questions.

\section{Results}

\subsection{Results of Reliability Analysis}

In order to pilot the teacher-made tests, the researcher administered them to a parallel pre-intermediate group of 30 students. Then, the characteristics of the individual item , $\mathrm{s}$, including item facilityitem discrimination, and the test characteristicsconsisting of reliability and validity, were determined. KR-21 method was used to determine the reliability of the tests. These two tests consisted of two forms, i.e. form A and form B which had the reliability index of 0.87 and 0.85 , respectively. While the former included two malfunctioning items, the latter included one. These three items were removed from both forms and the result was two 32 item tests to be used as pro-test and post-tests.

\subsection{Test of Homogenelty}

Before the treatment, the participants in all groups took the pretest The reason for this pre-testing was two-fold. First, to ensure the homogeneity of the two groups on their vocabulary performance to start the treatment, second, to have a criterion to developthe post-test resultsand the magnitude of gain- if any in each group's overall performance .

On the comparison between the pretest scores of the cooperative group (CG ) and the story-telling group (SG), the mean score and the standard devia tion were 15.8 and 2.63 respectivelyfor the CG, and 16.9 and 3.42 for the SG, respectively. The descriptive analysis of the pretest scores is presented in Table 1.

Table 1. Descriptive Statistics of the Pre-test in the SG and the CG

$\begin{array}{lcccc} & \text { Group } & \text { N } & \text { Mean } & \text { Std. Deviation } \\ \text { Pretest } & \text { CG } & 15 & 15.8 & 2.6 \\ & \text { SG } & 15 & 16.9 & 3.42\end{array}$

The standard deviations of the two groups show that the disparity of two sets of scores in the two groups is almost the same. Consequently, the researcher concluded that these two groups were at the same language ability.

In order to determine if the difference between the means of the scores of the two groups were significance on the pretest between means of the scores of the participants in both groups. The analysis indicated that no significant differences were found between the two groups. Asshown in Table 2, the difference between the two groups' performances, $t(28)=.12, p<05$, is insignificant.

Table 2. Independent samples $t$ test for the CG and SG CG and SG

\begin{tabular}{|c|c|c|c|c|c|}
\hline & $\underline{F}$ & $P$ & $d f$ & $T$ & $\mathrm{P}$ \\
\hline CG and SG & 2.12 & .15 & 28 & .12 & .90 \\
\hline
\end{tabular}

\subsection{The First Research Question}

The participants in two groups took the other parallel test again after the treatment as a post-test. In order to answer the first and second research questions, a paired sample t- test was run between the pre-test and post-test scores of each group to obtain the magnitude of gain- if any in each group's overall performance. 
Paired sample statistics and the t-test of the CG pre and posttest scores are shown in the following tables and figure :

Table 3. Paired Sample Statistics for CG

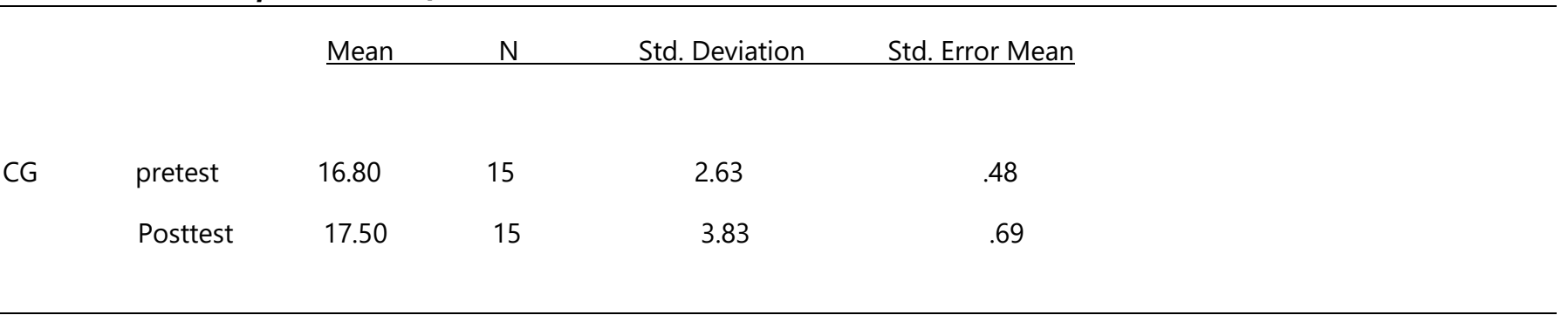

Table 4. Paired samples $t$ test for the CG's pretest and posttest

$\begin{array}{lccc} & \mathrm{df} & \mathrm{t} & \mathrm{p} \\ \text { Control group pretest and posttest } & 14 & -2.42 & .02\end{array}$

As shown in Table 3 and Table 4, the control group's performance, $t(14)=-2.42, p<05$, was found to be significantly better on the posttest-.

\section{Second Research Question}

Paired sample t-test was run to compare SG's scores before and after the treatment. The results are shown in the following tables:

Table 5. SG's pretest and postiest statistics

\begin{tabular}{|c|c|c|c|c|}
\hline Mean & $\mathrm{N}$ & Std. Devation & & $\underline{\text { Std. Error Mean }}$ \\
\hline Pretest & 16.90 & 153.42 & & .62 \\
\hline Posttest & 22.10 & 15 & 3.60 & .65 \\
\hline
\end{tabular}

Table 6. Paired samples $t$ test for the first experimental group pretest and posttest

\begin{tabular}{lcccc} 
SG pretest and posttest & df & $t$ & $p$ \\
\cline { 2 - 4 } & 14 & 39.86 & .00 \\
\hline
\end{tabular}

As can be seen from Table 5 and Table 6, the performance of the first experimental group,t $(14)=-39.86, p<05$, was found to be significantly better on the posttest.

\section{Research Question Three}

The first two hypotheses were rejected according to the above-elaborated tables. Now, in order to test the third hypothesis, an independent t-test was run between the posttest scores of the groups.

Table 7. Description Data Analysis of posttest in SG and CG

\begin{tabular}{ccccc}
\hline & Grouping & N & Mean & Std. Deviation \\
\cline { 2 - 5 } Posttest & CG & 15 & 17.50 & 3.83 \\
& SG & 15 & 22.10 & 3.60 \\
\hline
\end{tabular}


Table 8. Independent T- test samples for CG and SG

\begin{tabular}{llllllll}
\hline & & $F$ & $P$ & & & & \\
& & & & & & \\
& & & & & & & \\
& CG and SG & .25 & .61 & 28 & 4.79 & .00 \\
\hline
\end{tabular}

As the tables above present, the mean sources in both groups are 17.50 and 22.10 for CG and the SG, respectively. The standard deviations of the two groups show that the disparity of two scores in the two groups is different. Consequently, these findings, along with a high t- value in table 8 confirm that the subjects in SG performed better than the SG.

In order to provide a better picture of the achievements of the two groups one-way ANOVA is run to compare the pretest and posttest scores of the two groups. The results are shown below:

Table 9 One-way ANOVA for the pretest and posttest seores

Posttest

\begin{tabular}{lccccc} 
& \multicolumn{1}{c}{ Sum of Squares } & df & Mean Squares & F & Sig. \\
\cline { 2 - 6 } Between Groups & 155.806 & 2 & 77.903 & 27.473 & .000 \\
Within Groups & 121.933 & 28 & 2.836 & & \\
Total & 277.739 & 30 & & \\
\hline
\end{tabular}

The results of the one-way ANOVA test run for the scores of pretest and posttes $(F=27.47, p=.00)$ shows that there is a significant difference among the groups in terms of their scores on these tests. It can be argued that, according to the results shown in table 9, the treatment offered to the experimental group could make a statistically significant difference in their ability. In order to have a better picture of the improvements made in the groups a Scheffe posttest was run.

Table 10. Scheffe test for the reading comprehension posttest scores

Mean $\quad 95 \%$ confidence Interval



The mean difference is significant at the 0.05 level.

As shown in table 8, there is a significant difference between the pairs of CG pretest and posttest $(\mathrm{I}-\mathrm{J}=.58, \mathrm{p}-.00), \mathrm{CG}$ pretest and SG posttest $(1-J=, 57, p=00)$ and SG pretest and posttest $(I-J=.52, p=.00)$. However, the difference between CG pretest and SG 
posttest $(\mathrm{I}-\mathrm{J}=.63 \mathrm{p}=.35)$ is insignificant. The results confirm the fact that the treatment provided to the experimental group is significantly more effective than the one provided to the control group. A more careful glance at the table shows that both control group and experimental group students progressed through participating in the course; however, the ones in the story telling group could outperform the ones in the control group.

\section{Discussion}

In this chapter, all the research hypotheses had been tested through independent and paired samples T-test. A was mentioned earlier, the results of the independent t-testes in the first stage showed no differences among the $t$ wo groups before the instruction. Then, paired-samples t-test was run between each group's pretest and postet scores. While this second stage showed little progress in the CG performance, they showed a significant improvement in 'SGs, perfomance. Therefore the first two hypotheses were rejected. More over, having run an independent t-test for the posttest scores of the two groups to examine the efficiency of these two techniques, it was shown that the performance of SG was better than CG. Consequently, it can be interpreted that the treatment the SG had received was more influential in term of the students' vocabulary performance.

The results obtained in this study reveal that the treatment adopted in this study could significantly help the learners in SG to raise their mastery overusing the target words. This was statistically demonstrated to be true regarding the scores obtained by the learners on the postest. In the same line, concerning the results obtained regarding the effective learning of the participants in CG and SG, it can be argued that both collaborative and story-telling methods were significantly effective for vocabulary leaming.The effectiveness of cooperative learning found in this st udy is well supported by previous studies such as Javadi Rahavard(2010), Zarei and Keshavarz (2011), Tok (2012).

Considering the study's theoretical backgroundand the results obtained in previous studies regarding the issue, the obtained resu Its regarding the cognitive achievement of the learners were not absolutely far-fetched. AsCurtain and Dahlberg (2004) mentioned, and González (2010) and as shown by the findings of this studyit can be argued that adopting a context-based , approach with regard to word instruction leads to significant results in vocabulary leaming in EFL context.

The findings of this study are also in line with the output hypothesis framework put forward by Merrill Swain (1985) which supports comprehensible output by arguing that this type of output would enormously help the learner improveboth their fluency and accuracy. The findings of this study showed that using short stories and story-telling activities in class would boost learners' mastery over target word use since they have to focus on events happening one after another in the story. Moreover, the meaningful context provided inthe story and in the class were the story-telling as a meaningful real-world-like activity tales place to provide learnerswith authentic material and authentic context for using their language. The findings of this study may add to this perspective in that the outcome of a given teaching program would be better if it is presented in a contextual realworld-like production-based program.

From a theoretical perspective, as Ellis (1999) mentioned, communicative tasks such as story-telling, consider language as an instrument of communicationenable learners to use language communicatively and help teachers organize their courses , around semantic notions instead of pure grammar. As experts state, the relationship between vocabulary and communication in story-telling is non-hierarchical," in a sense that it helps teachers to provide authentic communicative contexts in their classrooms.

EFL students rarely have a chance to use English outside the classroom, and the aim of the English class is to equip students with vocabulary knowledge for the university entrance exam or other instrumental motives (Nasri, Namaziandost, \& Akbari, 2019). Whereas the concept of focus on form (Abedi, Namaziandost, \& Akbari, 2019)is now may be used in story-telling classes to draw learners' attention to word features in the communicative classroom, in a way that EFL teachers, similar to ESL counterparts, have a chance to make the heavy vocabulary- oriented classroom communicative.

In story-telling word teaching classes, vocabulary is witnessed as one of many resources that we have in language which helps us communicate. We should see how vocabulary relates to what we want to sayand how we expect others to interpret our language use andfocus.

\section{Conclusions, Implications and Suggestions}

Stories are used in both first and second language teaching. In L1 teaching, they are mainly utilized for teaching literacy, but in foreign language teaching, stories can be used at different ages and different levels to provide real-world-like contexts. While adopting this approach in teaching vocabulary throughmeaningful communicativecontext, this research attempted to compare applying such an approach to presenting new words to EFL..Learners with the cooperative approach. 
The present chapter aim s to provide a sound review of thestudy results anda discussion of the findings in light of the previous attempts made in the field regarding adopting short stories for vocabulary instruction. The chapter continuesbydescribing the possible implications of the study. Moreover, the suggestions for further search are presented in the final section.

As mentioned earlier in part four, the learners in this study had significantly improved their vocabulary knowledge in both groups. That is, cooperative instruction and using story-telling were both useful in terms of effectiveness. Moreover, the findings of this study show that using story-telling can be a good strategy to bypass the difficulty of vocabulary instruction since it gives learners chances of using new words communicatively to produce target forms in meaningful real-world contexts.

The findings of the study also confirm what is stated by (Hashemifardnia, Namaziandost, \& Sepehri, 2018) in that students are gaining greater confidence in using the language during such authentic real-world-like activities. Similarly, story-telling help teachers bring real-world experiences into the classroom by focusing on practical language skills.

According to Brown (2010), one of the characteristics of communicative language teaching is the use of authentic materials. It is necessary to give language learners opportunities to learn the language the way it is actually used in the real world. He sees authentic materials as a way to contextualize language learning. He continues when lessons are centred on comprehending a menu or a TV weather report, or a memory, students tend to focus more on content and meaning rather than the language itself and this offers the students a valuable source of language input, In addition to improving students' English language skills; using authentic language would expand their real-world knowledge about their chosen field of study.

\section{Implications of the Study}

There are a number of implications for syllabus designers, material developers, teachers as well as teacher trainers regarding the findings of this study:

1- The results of this study showed that although using both cooperative activities and stories could improve learners' performance on a vocabulary test, it could not make a difference in their learning. AsNamaziandost, Sawalmeh, and Izadpanah Soltanabadi (2020) stated, it is necessary to investigate such difficulties teachers and students face in specific contexts, take appropriate steps to overcome them and adapt methods to suit the actual teaching and learning environment. This is not to suggest to help leaders come over the difficulties. In other words, EFL curriculum and material developers should show an understanding of learners' and teachers' difficulties and provide sufficient guidance and help in the curriculum document and the teachers' book showing how the potential difficulties could be addressed in planning their classroom activities. Teachers may be given examples of mediating tasks, which would mitigate the difficulties. Moreover, students need to be taught words through various methodologies and approaches to cater to their individuallearning stylesand educators should consider students' attitudes and perceptions when making , decisions about how to teach new words. In addition, EFL teachers would do well to understand and address their learners" concerns in planning their lessons and classroom activities, and

supplementary materials, if necessary, to help learners cope with the difficulties. Both in-service and pre-service training programs should be planned in such a way that student-teachers and practising teachers articulate the potential and actual difficulties and discuss ways of overcoming or at least coping with them.

2- It is worth reminding the teachers that the important thing is balancingvocabulary teaching and communicative teaching. Since CLT is not banning explicit words teaching, teachers, material developers and teacher trainers can try to integrate them.

3- In teaching English as a foreign language, there have usually been concerns about students' negative feelings and attitudestowards new words. Word lists look boring and difficult to many language learners. There have been good improvements in teaching vocabulary by using story- telling in classes and/oracooperative approach since it seems that it motivates students to learn and use the target forms better in EFL classes. Certainly, an effective way of teaching vocabulary will contribute to both learners and teachers.

4- The subject of integrity out of class with class materials in EFL/ESL has been emphasised greatly. Some of them have referred to such issues by terms like authentic motivating or real materials. The results of such studies mostly demonstrate that language leaming is better achieved when new interesting topics are brought into students" class to be taught with their class materials. It seems that story-telling and using short stories may be well-formed effective way of adopting authentic material inthelanguage classroom .

Based on the findings of this study and in the light of the literature available regarding the topic under investigation in this study, the following lines of research are recommended: 
1- Using short stories and story-telling in EFL classrooms wasa promising technique in vocabulary teaching. There is a need to focus on story-telling in other aspects of language learning, such as pragmatic awareness.

2- The researcher could not repeat the posttest sometime later as a delayed assessment. It is suggested that future studies in the field plan fortheadministration of a delayed posttest to probe the effectiveness of the method - using stories or communicative approach - over time.

3- The researchers are better to compare story-telling with other authentic tasks in EFL classrooms at different proficiency levels to investigate the relative effectiveness of the available authentic techniques for teaching vocabulary or even other aspects of language learning such as collocation, idiom, and cultural or pragmatic awareness.

\section{References}

[1] Abedi, P., Namaziandost, E., \& Akbari, S. (2019). The impact of flipped classroom instruction on Iranian upper-intermediate EFL learners' writing skill. English Literature and Language Review, 5(9), 164-172.

[2] Aghlara, L., \& Hadidi Tamjid, N.(2011). The effect of digital games on Iranian children's vocabulary retention in foreign language acquisition. Procedia-Social and Behavioral Sciences, 29, 55-60.

[3] Allen, J. (1999). Words, words, words: Teaching vocabulary in grades 4 -12. York, Maine: Stenhouse Publishers.

[4] Anglin, J. M. (1993) Vocabulary development: A morphological analysis. Monographs of the Society for Research in Child Development, Serial No. $238,(10) 58$.

[5] Beck, I.L., \& MocKeown, M. (1991). Conditions of vocahulary acquisition. In R.Barr,M L. Kamil, P. MosenthalP. D. Pearson (Eds.), Handbook \& of reading research(Vol. 2, pp. 789-814). NewYork: Longman .

[6] Bolukabas, F., Keskin, F., \& Polat, M. (2011). The effectiveness of cooperative learning on reading comprehension skills in Turkish as foreign language. The Turkish Online Journal of Educational Technology, 10 (4), 330-335.

[7] Brown, D. (2010). Teaching by Principles. London: Longman.

[8] Chia-Wen, C. (2008). The effect of memory strategies instruction on vocabulary learning. Retrieved from the web April 3, 2021, from http://www.nlm.nih.gov/pubmed/15178532.

[9] Coady, J., \& Huckin, T. (2005). Second language vocabulary acquisition. Cambridge: Cambridge University Press.

[10] Craig, R. (1996). Storytelling in the classrooms: Some theoretical thoughts. Storytelling World, 7-9.

[11] Curtain, H., \& Dahlberg, C.A. (2004). Languages and children: Making the match. MA: Allyn Bacon.

[12] Dabaghmanesh, T., Zamanian, M., \& Bagheri, M. S. (2013). The effect of cooperative learning approach on Iranian EFL students' achievement among different majors in general English course. International Journal of Linguistics, 5(6), 1-11

[13] Ellis, G. \& J. Brewster. (2002). The Storytelling Handbook for Primary Teachers. New York Penguin Books.

[14] Ellis, R. (1999). Learning a second language through interaction. Amsterdam: John Benjaming.

[15] Fitzgibbon, H. B., \& Wilhelm, K. H. (1998). Storytelling in ESL/EFL classrooms. TESL Reporter 17, 21-31.

[16] Francis, M. A., \& Simpson, M. L.(2004).Using theory, our intuitions, and a research stady to enhance students' vocabulary knowledge.Journal of Adolescent \& Adult Literacy, 47(1),66-78.

[17] Gorjian, B., Moosavinia, S.R., \& Shahramiri, P. The effect of oral summary of short stories on speaking proficiency of pre-Intermediate EFL students: The case of gender study. Iranian EFL Journal, 7(1), (2011). 34-50.

[18] Harmer, J. (2005). The Practice of Language Teaching. London, Longman.

[19] Hashemifardnia, A., Namaziandost, E., \& Sepehri, M. (2018). The effectiveness of giving grade, corrective feedback, and corrective feedback-plus-giving grade on grammatical accuracy. International Journal of Research Studies in Language Learning, 8 (1), $15-27$.

[20] Hill, D. (2001). Survey: Graded readers. ELT Journal, 55)3),300-324.

[21] Hornby, AS. (1995). The Advanced Learner's Dictionary of Current English. In advance learners' dictionary of English.

[22] Jalilifar, A. (2010). The effect of cooperative learning techniques on college students' reading comprehension. System, 38(1), 96-108.

[23] Javadi Rahavard, Z. (2010). Cooperative learning strategies and reading comprehension California Linguistic Notes, 35(2), 1-15.

[24] Kowalski, C. (2001). Why not telling stories? JALT, 19(4), 10-15,23.

[25] Namaziandost, E., Hafezian, M., \& Shafiee, S. (2018). Exploring the association among working memory, anxiety and Iranian EFL learners' listening comprehension. Asian-Pacific Journal of Second and Foreign Language Education, 3(20), 1-17. https://doi.org/10.1186/s40862-018$\underline{0061-3}$.

[26] Namaziandost, E., Homayouni, M., \& Rahmani, P. (2020). The impact of cooperative learning approach on the development of EFL learners' speaking fluency. Cogent Arts \& Humanities, 7(1), DOI: 10.1080/23311983.2020.1780811.

[27] Namaziandost, E., Sawalmeh, M. H. M., \& Izadpanah Soltanabadi, M. (2020). The effects of spaced versus massed distribution instruction on EFL learners' vocabulary recall and retention. Cogent Education, 7(1). DOI: 10.1080/2331186X.2020.1792261.

[28] Namaziandost, E., Shatalebi, V., \& Nasri, M. (2019). The impact of cooperative learning on developing speaking ability and motivation toward learning English. Journal of Language and Education, 5(3), 83-101. https://doi.org/10.17323/jle.2019.9809.

[29] Nasri, M., \& Namaziandost, E. (2019). The impact of topic choice on descriptive writing ability among Iranian advanced EFL learners. International Journal of English Language Studies (IJELS), 1(1), 1-9.

[30] Nasri, M., Namaziandost, E., \& Akbari, S. (2019). Impact of pictorial cues on speaking fluency and accuracy among Iranian pre-intermediate EF learners. International Journal of English Language and Literature Studies, 8(3), 99-109.

[31] Pishghadam, R., \& Motakef, R. (2012). Narrative intelligence and learning languages. International Journal of Language Teaching and Research, 1(1), 13-20.

[32] Romero C. C. (2009). Cooperative learning instruction \& science achievement for secondary and early post-secondary students: A systematic Review. Unpublished Doctoral Dissertation, Colorado State University. USA. 
[33] Shakibaei, G., Shahamat, F., \& Namaziandost, E. (2019). The effect of using authentic texts on Iranian EFL learners' incidental vocabulary learning: The case of English newspaper. International Journal of Linguistics, Literature and Translation (IJLLT), 2(5), 422-432

[34] Sinatra, R., \& Dowd, C.A. (1991). Using syntactic and semantic clues to leam vocabulary. Journal of Reading, 35, $224-229$.

[35] Stevens, J. R. (2003). Student team reading and writing: A cooperative learning approach to middle school literacy instruction, Educational Research and Emulation.9 (2), 160-137.

[36] Swain, M. (1985). Communicative competence: some roles of comprehensible input and comprehensible output in its development". In Susan M. Gass and Carolyn G. Madden, eds. Input in second language acquisition, 235-253. Rowley, MA: Newbury House.

[37] Tahmasbi, S., Hashemifardnia, A., \& Namaziandost, E. (2019). Standard English or world Englishes: Issues of ownership and preference. Journal of Teaching English Language Studies, 7(3), 83-98.

[38] Tok, H. S. (2012). Cooperative learning and achievement in English language acquisition in a literature class in a secondary school. Unpublished master thesis, Universiti Teknologi Malaysia, Malaysia.

[39] Ur, P. (1998). A Course in Language Teaching. Cambridge: Cambridge University press.

[40] Wang. D. (2006). What can standardize reading tests tell us? Question-answer relationships and students' performance. Journal of College Reading and Learning.36(2).21-37.154.

[41] Zahedia, Y., \& Abdib, M. (2012). The effect of semantic mapping strategy on EFL learners vocabulary learning. Procedia-Social and -Behavioral Sciences, 69, 2273-2280.

[42] Zarei, A.A., \& Keshavarz, J. (2011). On the effects of two models of cooperative learning on EFL reading comprehension and vocabulary learning. Modern Journal of Language Teaching Methods,1(2),39-51.

[43] Zawada, J. (2012). Story telling as a tool for teaching past simple tense at primary level Retrieved from http://7.www.publikacje.edu.pl/pdf9893.pdf. 